\title{
The impact of weather forecasting advisory services in decision taken in field operation
}

\author{
RAJESH, A.K. GODARA, S.K. MEHTA, C.D. AUTADE AND GAGAN MEHTA
}

Article Chronicle :

Received :

20.10.2016;

Revised:

16.11.2016;

Accepted :

27.11.2016

\section{Key Words :}

Impact,

Weather

forecasting,

Weather

forecasting

advisory services
ABSTRACT : Weather and climate condition influence the society and economy. In addition year to year variation to timing, intensity and duration of seasonal precipitation and extreme temperature has large impact on people and physical landscape. Seasonal climate forecast provide probabilistic monthly or seasonal climate prediction for the forthcoming year. Agricultural activities are very dependent on climatic condition. The failure of crop to produce good yield is very often due to bad climate. Capability of farmers to use climate forecast to anticipate the events is very limited. Farmers and farming community throughout the world survived and developed by mastering the ability to adopt widely varying weather and climate conditions. However, dramatic growth in human population is imposing enormous pressure on existing farming production system. Knowledge of seasonal climatic forecast allows farmers and other user of climate information to develop seasonal management strategies learning to potential improvement in the productivity. Benefit arises when the use of forecasts results in decisions that reduce the vulnerability of human populations to the adverse impacts of climate variability. The focus here is on impacts of climate variability on agricultural production systems and decisions related to their management. We can represent the opportunity to benefit as falling within the intersection of human vulnerability, climate predictability and decision capacity.

HOW TO CITE THIS ARTICLE : Rajesh, Godara, A.K., Mehta, S.K., Autade, C. D. and Mehta, Gagan (2016). The impact of weather forecasting advisory services in decision taken in field operation. Asian J. Environ. Sci., 11(2): 160-163, DOI: 10.15740/HAS/AJES/11.2/160-163.
Author for correspondence :

\section{D. AUTADE}

Department of

Extension Education,

College of Agriculture,

Chaudhary Charan Singh

Haryana Agriculture

University, HISAR

(HARYANA) INDIA

Email : charudattautade@

gmail.com

See end of the article for

Coopted authors' 